\title{
Response to combination of sofosbuvir and daclatasvir in chronic hepatitis $\mathbf{C}$ infection.
}

\footnotetext{
1. MBBS, FCPS (Medicine), FCPS (Gastroenterology) Professor Medical Unit 1 Sheikh Zayed Medical College/ Hospital, Rahim Yar Khan.

2. MBBS, FCPS (Gastroenterology) Assistant Professor

Gastroenterology Sheikh Zayed Medical College/ Hospital, Rahim Yar Khan.

3. MBBS, FCPS (Gastroenterology) Senior Registrar Gastroenterology Sheikh Zayed Medical College/ Hospital, Rahim Yar Khan.
}

Correspondence Address:

Dr. Irfan Ahmad

C-4, Medical Colony,

Sheikh Zayed Medical College/

Hospital, Rahim Yar Khan.

uhirfan@yahoo.com

Article received on:

$11 / 05 / 2020$

Accepted for publication:

$15 / 08 / 2020$

\begin{abstract}
Irfan Ahmad', Muhammad Israr ul Haq², Ghulam Abbas ${ }^{3}$
ABSTRACT... Objectives: To determine efficacy of sofosbuvir and daclatasvir in the treatment of chronic hepatitis C infection. Study Design: Experimental study. Setting: Hepatitis Clinic, Sheikh Zayed Medical College/Hospital, Rahim Yar Khan. Period: June to December 2018. Material \& Methods: Five hundred patients having chronic hepatitis $C$ infection including those with compensated cirrhosis were included in the study. They were given sofosbuvir $400 \mathrm{mg}$ daily and daclatasvir $60 \mathrm{mg}$ daily. Weight based ribavirin was added if patient has evidence of cirrhosis. Treatment duration was 12 weeks for non-cirrhotic and 24 weeks for cirrhotics. End of treatment response (ETR) was recorded. Results: Mean age of the included patients was $41 \pm 11.69$ with range from 8 to 82 years, while $217(43.4 \%)$ patients were male and $283(56.6 \%)$ were female. Cirrhosis was present in $59(11.8 \%)$ patients; among these $35.6 \%$ were in Child A and $64.4 \%$ in early Child B. End of treatment response occurred in $491(98.2 \%)$ patients and there was no significant difference in ETR between male and female patients, and between cirrhotic and non-cirrhotic. Similarly, there was no significant difference in age between those having ETR and those having no ETR. Fatigue was experienced by $13.2 \%$ and headache by $4.2 \%$ patients. Conclusion: The combination of sofosbuvir and daclatasvir has high response rate in chronic hepatitis $\mathrm{C}$ patients of our population.
\end{abstract}

Key words: Compensated Cirrhosis, Daclatasvir, End of Treatment Response, Hepatitis C, Sofosbuvir.

Article Citation: Ahmad I, Israr ul Haq M, Abbas G. Response to combination of sofosbuvir and daclatasvir in chronic hepatitis C infection. Professional Med J 2020; 27(12):2596-2600. https://doi.org/10.29309/TPMJ/2020.27.12.4787

\section{INTRODUCTION}

Globally, about 100 million population have antiHCV antibodies positive and 70 million people are suffering from chronic hepatitis C. ${ }^{1}$ The most common cause of cirrhosis in our population is hepatitis $\mathrm{C}$ virus $(\mathrm{HCV})$ infection. In southern part of Punjab, prevalence of hepatitis C infectivity was 8 to $24 \%{ }^{2,3}$ After an acute infection, $50-$ $85 \%$ patients develop chronic hepatitis C. ${ }^{4}$ Cirrhosis develops after 20 years among $16 \%$ of these patients. ${ }^{5}$ Cirrhotic patients develop hepatocellular carcinoma ( $\mathrm{HCC})$ at a rate of upto $3 \%$ per year. $^{6}$

Keeping in view these life threatening sequel of hepatitis C infection, it is important to detect and treat these patients at an early stage, before development of cirrhosis which is irreversible. Chronic hepatitis $\mathrm{C}$ patients had been treated with Interferon alpha since late $1980 \mathrm{~s}^{7}$ with little benefit ${ }^{8}$, even after prolonging the treatment duration from 24 to 48 weeks ${ }^{9}$ but addition of ribavirin resulted in greater efficacy (SVR rose from 6 to $40 \%$ ). ${ }^{10,11}$ Replacement of interferon with pegylated interferon further improved the SVR rate $(54-61 \%) .{ }^{12}$ In addition to low response rate, this regimen had high profile of side effects. ${ }^{13,14}$ Boceprevir and telaprevir, directly acting antivirals (DAAs), were used in 2011 and these improved response rate to $65-75 \%^{15,16}$ but had to be given with pegylated interferon plus ribavirin and again had higher side effect profile. New oral DAAs became available since 2013 which have higher efficacy and lower rate of side effects. Two combinations are available in Pakistan: sofosbuvir and daclatasvir, sofosbuvir and velpatasvir; both have response rates of 95 to $100 \%{ }^{7,17,18}$ Both of these combinations are pangenomic. 
Sofosbuvir along with daclatasvir are being prescribed to our patients due to their availability and low cost. As the efficacy of hepatitis C treatment varies with genotype and other patient factors, we carried out this study to look for the success rate of this combination in our local population.

Our study had the objective of determining the response rate of sofosbuvir plus daclatasvir in patients of chronic hepatitis $\mathrm{C}$ virus infection.

\section{MATERIAL \& METHODS}

This was an experimental study conducted at Hepatitis clinic, Sheikh Zayed Medical College/ Hospital, Rahim Yar Khan from June 2018 up to December 2018.

Five hundred patients having chronic hepatitis $\mathrm{C}$ who attended our outpatient clinic for treatment were included in our study. Both patients without cirrhosis and those with compensated cirrhosis were included. For inclusion patients had to be treatment naïve. Exclusion criteria were decompensated cirrhosis, previously treated patients, co-infection with HIV, pregnancy, concomitant fatty liver disease, alcoholism, renal failure, and presence of liver cancer.

Every patient enrolled in the study was specially asked about the presenting complaints and associated symptoms, current usage of drugs and the presence of comorbidities. Routine blood tests were advised including complete blood count (CBC), prothrombin time (PT), liver function tests (LFTs), albumin and creatinine. Qualitative PCR for HCV RNA was sent and ultrasound abdomen was done.

Included patients were given sofosbuvir one tablet of $400 \mathrm{mg}$ once per day and daclatasvir tablet of $60 \mathrm{mg}$ once per day. Ribavirin was added according to the weight of the patient $(500 \mathrm{mg}$ twice daily for those having weight less than 75 $\mathrm{kg}$ and $600 \mathrm{mg}$ twice daily for those having weight more than $75 \mathrm{~kg}$ ) if there was clinical, biochemical and ultrasonographic evidence of cirrhosis. Treatment was given for 12 weeks in non-cirrhotic and for 24 weeks in those having cirrhosis. After completion of treatment duration, qualitative HCV RNA (PCR) was advised and result of end of treatment response (ETR) recorded. Side effects of drugs were also noted.

The data was analyzed by using software SPSS version 25. After describing as frequency and percentage, the qualitative data was analyzed using Chi-square test. Mean \pm SD and range were used to express the quantitative data which was analyzed by Student's t-test. A p value of $<0.05$ was considered as having statistical significance. Analysis was done for whole of study population and also for non-cirrhotic and cirrhotic groups separately.

Approval for study protocol was taken from Institutional Review Board and Ethical Committee.

\section{RESULTS}

Female patients were more than male and the patients included had mean age of about 42 years (Table-I). Fifty nine \% (295) patients were in fourth or fifth decade of life. Male patients have mean age of $42.31 \pm 12.96$ years and female have mean age of $41.64 \pm 10.64$. The difference between their ages was not of statistically significance ( $p$ $=0.529$ ). About $12 \%$ (59) patients were cirrhotic. Among these, 21 (35.6\%) had Child A and 38 $(64.4 \%)$ had Child B cirrhosis. Eleven (18.64 \%) cirrhotic had ascites. Cirrhotic were older than non-cirrhotic (mean ages $46.34 \pm 9.46$ vs 41.34 $\pm 12.96)$ and this difference was significant $(p=$ 0.002).

\begin{tabular}{|l|c|}
\hline \multicolumn{1}{|c|}{ Variables } & Results \\
\hline Age in years \pm SD (range) & $41.93 \pm 11.70$ \\
& $(8$ to 82 years) \\
\hline Gender & \\
Male & $217(43.4 \%)$ \\
Female & $283(56.6 \%)$ \\
\hline Non-cirrhotic & $441(88.2 \%)$ \\
\hline Cirrhotic & $59(11.8 \%)$ \\
\hline
\end{tabular}

Table-I. Demographic features of 500 patients

HCV RNA PCR negativity after completion of treatment i.e., ETR was observed in 491 patients $(98.2 \%)$. Mean age of responders was $41.90 \pm 11.61$ and of non-responders $43.78 \pm$ 
16.26 ( $p=0.633)$. The response rate was not significantly different in male and female patients, and between cirrhotic and non-cirrhotic (TableII). Sixty six patients (13.2\%) complained of fatigue and 21 patients (4.2\%) had headache. Among 59 cirrhotic patients who were given ribavirin, 11 (18.64\%) developed cough and mild breathlessness on exertion which responded to symptomatic treatment. Ten of these patients (16.95\%) had drop in hemoglobin below $10 \mathrm{~g} /$ dl for which dose of ribavirin had to be adjusted. None of the serious side effects occurred requiring treatment discontinuation.

\begin{tabular}{|l|c|c|c|}
\hline $\begin{array}{l}\text { Dependent } \\
\text { Variable }\end{array}$ & Yes & No & P-Value \\
\hline $\begin{array}{l}\text { Gender } \\
\text { Male } \\
\text { Female }\end{array}$ & 211 & 6 & 0.186 \\
\hline $\begin{array}{l}\text { Cirrhosis } \\
\text { Not present }\end{array}$ & 280 & 3 & 1.000 \\
Present & 58 & 8 & \\
\hline \multicolumn{1}{|c|}{ Table-II. ETR - gender wise and according to } \\
presence of cirrhosis
\end{tabular}

\section{DISCUSSION}

Sofosbuvir, a NS5B inhibitor, was the first oral $\mathrm{DAA}^{19}$ that drastically changed the treatment of hepatitis $\mathrm{C}^{20}$ It was followed by development of many other DAAs. It has good efficacy against all genotypes of hepatitis $\mathrm{C}^{21}$ In our country genotype 3 accounts for more than $80 \%$ of hepatitis C patients. $^{22,23}$ This genotype is considered to be less responsive to DAAs. ${ }^{24}$ Sofosbuvir was initially used with ribavirin for genotype 2 and 3 patients. In Fission and Positron trials, SVR with this combination in genotype 3 were $56 \%$ and 61 $\%$ respectively. ${ }^{25,26}$ In Pakistan SVR with it was 83 $\% .{ }^{20}$ Daclatasvir is NS5A inhibitor and used along with sofosbuvir for genotype 2 and 3 patients. This combination is proved to be more effective than sofosbuvir with ribavirin. ${ }^{27}$

In ALLY-3 study, sofosbuvir plus daclatasvir were given without ribavirin to hepatitis $C$ genotype 3 treatment naïve patients for 12 weeks. Overall, ETR was > $99 \%$ and SVR12 $90 \%$ (96\% for patients having no cirrhosis and $63 \%$ for those having cirrhosis). ${ }^{18}$ In another study, this combination was given with or without ribavirin for 24 weeks to treatment naïve patients of genotypes 1, 2 and 3 . SVR12 were $98 \%, 92 \%$ and $89 \%$ respectively. ${ }^{28}$ Poordad et al gave this combination with ribavirin to cirrhotic hepatitis $\mathrm{C}$ patients for 12 weeks. SVR12 for genotypes 1, 2, 3 and 4 were $82 \%, 80$ $\%$, $83 \%$ and $100 \%$ respectively. ${ }^{29}$ Considering local data, when sofosbuvir and daclatasvir combination was given, overall both end of treatment response and SVR24 were $98.84 \%{ }^{30}$ About $10 \%$ of these patients were cirrhotics. Similary, Azmat A, et al showed a ETR of $98.8 \%$ and SVR12/24 of $96.25 \%{ }^{7}$ All of their patients were of genotype 3 . Our result (ETR $98.2 \%$ ) is similar to local studies. It indicates that hepatitis $\mathrm{C}$ patients in Pakistani population respond better to sofosbuvir and daclatasvir.

We did not check genotype status of the patients due to cost issue but we assume that genotype 3 would be most common as all local studies favor this finding. ${ }^{22,23}$ We could not determine SVR12 as most of our patients lost in follow up but as our ETR is similar to that of other local studies, ${ }^{7,30}$ it can be assumed that SVR will also be similar to them. Side effects profile and tolerability of drugs in our study were same as in other local and international studies. ${ }^{7,28}$

\section{CONCLUSION}

The combination of two DAAs, sofosbuvir and daclatasvir, is very effective for the treatment of chronic hepatitis C patients of Southern Punjab like other regions of our country. These drugs have good tolerability and generally safe to use.

Copyright(C) 15 Aug, 2020.

\section{REFERENCES}

1. Polaris observatory HCV collaborators. Global prevalence and genotype distribution of hepatitis C virus infection in 2015: A modelling study. Lancet Gastroenterol Hepatol 2017; 2 (3):161-76

2. Aslam MN, Nadeem M, Qureshi UF. HEPATITIS B AND C. The Professional Medical Journal. 2016 Jan 10;23(01):025-8.

3. Zafar Majeed, MA Manzoor, Aasma Manzur. Prevalence of hepatitis $B$ and hepatitis $C$ viral infection in the rural population of Rahim Yar Khan. JSZMC 2012; 3 (2):310-3. 
4. Grebely J, Page K, Sacks-Davis R, van der Loeff MS, Rice TM, Bruneau J, et al. The effect of female sex, viral genotype, and IL28B genotype on spontaneous clearance of acute hepatitis $\mathbf{C}$ virus infection. Hepatology 2014; 59 (1):109-20.

5. Thein $\mathrm{HH}, \mathrm{Yi}$ Q, Dore GJ, Krahn MD. Estimation of stage-specific fibrosis progression rates in chronic hepatitis $C$ virus infection: $A$ meta-analysis and meta-regression. Hepatology 2008; 48 (2):418-31.

6. Hu KQ, Tong KJ. The long-term outcomes of patients with compensated hepatitis $C$ virus-related cirrhosis and history of parenteral exposure in the United States. Hepatology 1999; 29 (4):1311-6.

7. Azmat A, Sheikh M, Azim S, Saeed M, Abbasi S. Response rates to sofosbuvir and daclatasvir in chronic hepatitis C patients. J Med Sci 2019; 27 (2):85-9.

8. Davis LG, Balart LA, Schiff ER, Lindsay K, Bodenheimer $\mathrm{HC}$, Perrillo RP, et al. Treatment of chronic hepatitis $C$ with recombinant interferon alpha. $\mathrm{N}$ Eng $\mathrm{J}$ Med 1989; 321 (22): 1501-6.

9. Poynard T, Bedossa $P$, Chivallier $M$, Mathurin $P$, Lemonnier C, Trepo C, et al. A comparison of three interferon alpha-2b regimen for the long-term treatment of chronic non-A, non-B hepatitis. N Eng J Med 1995; 332 (22): 1457-63.

10. McHutchison JG, Gordon SC, Schiff ER, Shiffman ML, Lee WM, Rustgi VK, et al. Interferon alpha-2b alone or in combination with ribavirin as initial treatment of chronic hepatitis C. N Eng J Med 1998; 339 (21): 148592.

11. Niaz A. Response to interferon alone and with ribavirin in patients of chronic hepatitis C. JCPSP 2002; 13 (8): 433-5.

12. Fried MW, Shiffman ML, Reddy KR, Smith C, Marinos G, Goncales FL, et al. Peginterferon alpha-2a plus ribavirin for chronic hepatitis $\mathbf{C}$ infection. N Eng $\mathbf{J}$ Med 2002; 347 (13): 975-82.

13. Muhammad Umar, Tayyab Saeed Akhter. New direct acting antiviral agents for the treatment of hepatitis C: 2016 and beyond. JCPSP 2016; 26 (10):843-50.

14. Hamid S, Umar M, Alam A, Siddiqui A, Qureshi H, Butt J. PSG consensus statement on management of hepatitis C virus infection. J Pak Med Assoc 2004; 54 (3):146-50.

15. Poordad F, McCone J, Bacon BR, Bruno S, Manns MP, Sulkowski MS, et al. Boceprevir for untreated chronic HCV genotype 1 infection. N Eng J Med 2011; 364 (13): 1195-1206.
16. Jacobson IM, McHutchison JG, Dusheiko G, Di Bisceglie AM, Reddy KR, Bzowej NH, et al. Telaprevir for previously untreated chronic hepatitis $\mathbf{C}$ virus infection. N Eng J Med 2011; 364 (25):2405-16.

17. Foster GR, Afdhal N, Roberts SK, Brau N, Gane EJ, Pianko S, et al. Sofosbuvir and velpatasvir for HCV genotype 2 and 3 infection. N Eng J Med 2015; 373 (27):2608-17.

18. Nelson DR, Cooper JN, Lalezari JP, Lawitz E, Pockros PJ, Gitlin N, et al. All-oral 12 week treatment with daclatasvir plus sofosbuvir in patients with hepatitis C virus genotype 3 infection: ALLY-3 phase III study. Hepatology 2015; 61 (4):1127-35.

19. Marino Z, Bommel FV, Forns X, Berg T. New concepts of sofosbuvir-based treatment regimens in patients with hepatitis C. Gut 2014; 63 (2): 207-15.

20. Sarwar S, Khan AA. Sofosbuvir based therapy in hepatitis $\mathbf{C}$ patients with and without cirrhosis: Is there difference? Pak J Med Sci 2017; 33 (1): 37-41.

21. Cholongitas E, Papatheodoridis GV. Sofosbuvir: A novel oral agent for chronic hepatitis C. Annals of Gastroenterology 2014; 27(4):331-7l.

22. Tayyab GN, Haque I, Salam T, Abid S, Shahid N. Adverse effect profile of patients receiving anti-viral treatment for chronic hepatitis $\mathbf{C}$ virus infection. Ann King Edward Med Coll 2005; 11 (4): 445-6.

23. Siddique MS, Shoaib S, Saad A, Iqbal HJ, Durrani N. Rapid virological \& End treatment response of patients treated with Sofosbuvir in Chronic Hepatitis C. Pak J Med Sci 2017; 33 (4): 813-7.

24. Feld JJ, Foster GR. Second generation direct-acting antivirals - Do we expect major improvements? Hepatol 2016; 65(1Suppl):S130-S142.

25. Lawitz E, Mangia A, Wyles D, Rodriguez-Torres M, Hassanein T, Gordon SC, et al. Sofosbuvir for previously untreated chronic hepatitis $\mathbf{C}$ infection. $\mathrm{N}$ Engl J Med 2013; 368 (20): 1878-87.

26. Jacobson IM, Gordon SC, Kowdley KV, Yoshida EM, Rodriguez-Torres M, Sulkowski MS, et al. Sofosbuvir for hepatitis $\mathbf{C}$ genotype 2 or $\mathbf{3}$ in patients without treatment options. N Engl J Med 2013; 368 (20): 186777.

27. Gupta V, Kumar A, Sharma P, Arora A. Newer directacting antivirals for hepatitis $\mathbf{C}$ virus infection: Perspective for India. Indian J Med Res 2017; 146 (1): 23-33. 
28. Sulkowski MS, Gardiner DF, Torres MR, Reddy KR, Hassanein $T$, Jacobson I, et al. Daclatasvir plus sofosbuvir for previously treated or untreated chronic HCV infection. N Eng J Med 2014; 370 (3): 211-21.

29. Poordad F, Schiff ER, Vierling JM, Landis C, Fontans RJ, Yang $R$, et al. Daclatasvir with sofosbuvir and ribavirin for hepatitis $\mathrm{C}$ virus infection with advanced cirrhosis or post-liver transplantation recurrence. Hepatology 2016; 63 (5): 1493-1505.
30. Jamali Anwar A, Jamali GM, Jamali Ameer A. Virological responses in chronic hepatitis $C$ patients, treated with sofosbuvir and daclatasvir versus sofosbuvir and ribazole. Ann Pak Inst Med Sci 2018; 14 (2): 17781.

\begin{tabular}{|c|c|c|c|}
\hline \multicolumn{4}{|c|}{ AUTHORSHIP AND CONTRIBUTION DECLARATION } \\
\hline Sr. \# & Author(s) Full Name & Contribution to the paper & Author(s) Signature \\
\hline 1 & Irfan Ahmad & $\begin{array}{l}\text { Conception of idea, Study design, } \\
\text { Data collection, Literature review, } \\
\text { manuscript writing, data analysis, } \\
\text { interpretation of resutls. }\end{array}$ & \\
\hline 2 & M. Israr ul Haq & $\begin{array}{l}\text { Conception of idea, data collection, } \\
\text { data analysis, interpretation of } \\
\text { resutls, proof reading. }\end{array}$ & \\
\hline 3 & Ghulam Abbas & $\begin{array}{l}\text { Conception of idea, data collection, } \\
\text { Data analysis, Interpratation of } \\
\text { results. }\end{array}$ & \\
\hline
\end{tabular}

